\title{
PENGEMBANGAN MODUL PEMBELAJARAN KIMIA PADA MATERI POKOK LARUTAN ELEKTROLIT DAN NONELEKTROLIT BERBASIS INKUIRI TERBIMBING (GUIDED INQUIRY)
}

\author{
Eka Rahmatul Aidha \\ Jurusan Pendidikan Kimia Universitas Negeri Padang \\ Email: eka.aidha@yahoo.com
}

\begin{abstract}
Issue formal education become a common topic today is the low student learning outcomes. Based on the research conducted so far, it turns out low yields due to student learning in general chemistry students have difficulty in analyzing chemical material that is both abstract and resolve problems related to chemical reactions, this happens due to lack of understanding by students. One of the learning strategies that encourage students to seek and find something in learning is through guided inquiry strategies. In support of this strategy, the group used the system to learn and make teaching materials in the form of chemistry learning modules based on guided inquiry learning cycle. The subjects were students of class X SMA Negeri 1 Lubuk Alung. This type of research is the development of research with the development of type $4 D$ models. Validation results showed that the chemistry learning modules in the subject matter of electrolyte and nonelectrolyte solution has a moment kappa of 0.84. These results reveal that, the product is in conformity with the curriculum and the correct concept. Field trial results show the practicality of the value of products made based on the assessment of teachers' questionnaire responses with kappa of 0.91 and a moment of assessment student questionnaire responses by 0.95. Based on the results of this study concluded that the developed learning modules are very practical for use in the learning process. It is also proved by testing students' understanding of the effectiveness of a product with an average score of 85.8. It can be concluded that using the students' understanding of chemistry learning modules in the category so well that the product is very effective for use in learning.
\end{abstract}

Keywords: Learning Module Chemistry, Main Material Electrolytes and Nonelectrolytes, Guided Inquiry.

\section{PENDAHULUAN}

Peningkatan penguasaan dan pemahaman siswa terhadap materi pelajaran menjadi tujuan utama dalam proses pembelajaran di sekolah. Tingkat keberhasilan dalam proses pembelajaran tersebut tidak lepas dari peranan seorang guru. Guru sebagai komponen utama dalam proses pembelajaran memegang peranan penting dalam mencapai tujuan pendidikan. Guru diharapkan mampu menciptakan kondisi belajar sedemikian rupa sehingga dapat merangsang siswa untuk belajar secara aktif.

Dalam menjalankan fungsinya, guru dituntut memiliki kompetensi, yaitu seperangkat pengetahuan, keterampilan dan perilaku yang harus dimiliki, dihayati, dan dikuasai oleh guru dalam melaksanakan tugas keprofesionalan. Seperti yang dinyatakan Sanjaya (2008:25) bahwa dalam proses pembelajaran, guru sebagai pengelola pembelajaran (manager of learning) memiliki empat fungsi umum, yaitu:

1. merencanakan tujuan belajar,

2. mengorganisasikan berbagai sumber belajar untuk mewujudkan tujuan belajar,

3. memimpin, yang meliputi memotivasi dan menstimulasi siswa,

4. mengawasi segala sesuatu, apakah sudah berfungsi sebagaimana mestinya atau belum dalam rangka pencapaian tujuan.

Dari kutipan di atas, terlihat bahwa dari empat fungsi umum guru tersebut diharapkan guru mampu menerapkan strategi pembelajaran yang tepat sehingga siswa dapat terlibat secara aktif, baik fisik, mental maupun sosial dalam proses pembelajaran. Strategi pembelajaran yang digunakan oleh guru akan berpengaruh terhadap kualitas pembelajaran yang dilakukan.

Guru sebagai ujung tombak dalam implementasi kurikulum 2013 dituntut 
menjadi pengajar yang mampu meramu komponen kurikulum 2013 secara cepat dan tepat yakni standar isi, proses, penilaian dan kompetensi lulusan. Dengan adanya komponen kurikulum 2013 diharapkan mampu meningkatkan keseimbangan kompetensi siswa untuk menghasilkan lulusan yang mampu menjawab tantangan global. Peserta didik harus menyadari bahwa pendidikan diperlukan untuk menjawab tantangan global. Siswa juga harus bertanggung jawab dalam menuntut ilmu untuk mencapai pendidikan karakter yang menjadi tujuan kurikulum 2013.

Pelajaran kimia kelas X SMA semester dua mengenai materi pokok larutan elektrolit dan nonelektrolit siswa dituntut untuk memahami konsep-konsep yang meliputi: tanda-tanda hantaran listrik melalui larutan, mengidentifikasi sifat-sifat larutan elektrolit dan nonelektrolit, mengelompokkan larutan ke dalam larutan elektrolit kuat, larutan elektrolit lemah dan larutan nonelektrolit berdasarkan hantaran listriknya, menjelaskan penyebab kemampuan larutan elektrolit dapat menghantarkan arus listrik, dan mendeskripsikan bahwa larutan elektrolit dapat berupa senyawa ion dan senyawa kovalen polar. Materi-materi ini bersifat abstrak, maka diperlukan imajinasi yang kuat dari siswa untuk membaca dan menganalisis materi pokok tersebut, sehingga membuat siswa kesulitan untuk memahaminya karena penyajian materi yang diterapkan selama ini kurang menarik bagi siswa. Kebanyakan guru mengajarkannya tanpa menggunakan media pembelajaran, sehingga siswa kurang termotivasi dalam belajar. Akibatnya siswa sukar untuk memahami konsep-konsep yang terkandung dalam materi ini.

Salah satu alternatif yang dapat digunakan untuk mengatasi keterbatasan dalam pelaksanaan pembelajaran adalah dengan menerapkan strategi pembelajaran inkuiri terbimbing (guided inquiry). Menurut Hanson (2006: 3) inkuiri terbimbing merupakan suatu strategi karena menyediakan metodologi dan struktur tentang cara belajar dan hasil yang diinginkan. Strategi inkuiri terbimbing ini menekankan kepada aktivitas siswa secara maksimal untuk mencari dan menemukan jawaban dari suatu masalah yang dipertanyakan. Strategi ini mengakui bahwa orang belajar dengan membangun pemahaman berdasarkan pengetahuan awal; mengikuti siklus belajar berupa eksplorasi, pembentukan konsep, dan aplikasi; berdiskusi dan berinteraksi dengan orang lain (Hanson, 2005:1).

Pemilihan modul pembelajaran kimia berbasis inkuiri terbimbing berdasarkan observasi ke sekolah bahwa belum ada ditemukan modul pembelajaran kimia khusus untuk materi pokok larutan elektrolit dan nonelektrolit. Dalam mendukung strategi pembelajaran berbasis inkuiri terbimbing ini, digunakan sistem belajar kelompok dan membuat modul pembelajaran kimia yang didasarkan pada siklus belajar inkuiri terbimbing, yaitu eksplorasi, pembentukan konsep, dan aplikasi. Sebagaimana yang dikemukakan oleh Suryosubroto (1983: 12) bahwa dengan adanya modul siswa dapat belajar sendiri tanpa terikat tempat dan waktu dan tidak terlalu tergantung pada guru, sehingga kegiatan pembelajaran lebih efektif dan efisien.

Pada tahap eksplorasi siswa memiliki kesempatan melakukan pengamatan dan menganalisis data atau informasi yang berupa gambar, grafik, tabel data, atau rumus. Pada tahap pembentukan konsep siswa diberikan pertanyaan-pertanyaan yang mendorong siswa untuk berpikir kritis. Pertanyaan-pertanyaan ini disebut key questions (pertanyaan kunci) yang memandu siswa dalam eksplorasi. Pertanyaan-pertanyaan tersebut dapat membantu mengarahkan siswa ke informasi yang dituju, menuntun siswa menemukan hubungan dan kesimpulan yang sesuai, serta membantu siswa membangun pemahaman tentang konsep yang sedang dipelajari. Pada tahap aplikasi siswa diberi latihan yang bertujuan memberi siswa kesempatan untuk membangun kepercayaan diri dalam situasi yang sederhana. Dengan kegiatan inkuiri terbimbing ini akan membantu siswa mengembangkan pemahaman.

Berdasarkan uraian di atas, salah satu usaha yang dapat dilakukan untuk meningkatkan pemahaman siswa terhadap materi pembelajaran yaitu dengan mengembangkan bahan ajar inkuiri terbimbing berupa modul. Dengan menggunakan modul diharapkan siswa dapat belajar sendiri tanpa tergantung pada guru. Pada modul ini berisi model, pertanyaan kunci dan latihan. Dimana pertanyaan kunci ini siswa mengembangkan jawaban dengan memikirkan apa yang mereka temukan dalam 
model, sehingga siswa sendiri yang menemukan konsep. Peran guru sebagai fasilitator dan motifator dalam proses pembelajaran tanpa memberikan jawaban benar atas pertanyaan yang diberikan kepada siswa.

Dalam proses pembelajaran, siswa dituntut untuk berpikir kritis. Karena itu pembelajaran kimia dilakukan dengan menggunakan alat bantu/ modul berwarna yang dilengkapi informasi/ model berupa gambar, rumus, tabel data, atau grafik. Dalam lembaran kegiatan siswa pada modul, diusahakan seminimal mungkin informasi verbal. Model/ informasi yang disajikan dalam bentuk gambar, rumus, tabel data, atau grafik, dalam pembentukan konsep siswa diberikan pertanyaan-pertanyaan kunci untuk mengarahkan siswa ke informasi yang dituju, menuntun siswa menemukan hubungan dan kesimpulan yang sesuai, dan membantu siswa membangun pemahaman tentang konsep yang sedang dipelajari, dan dilengkapi latihan. Siswa belajar untuk menemukan konsep dengan cara mempelajari gambar, rumus, tabel data, atau grafik yang diberikan, kemudian siswa menjawab pertanyaan kunci yang diberikan. Dengan demikian, siswa aktif menemukan sendiri pengetahuan dengan cara belajar mandiri sehingga inkuiri terbimbing dalam pembelajaran dapat terjadi. Terjadinya pemahaman yang lebih mudah diprediksi akan meningkatkan motivasi siswa untuk mempelajari materi selanjutnya.

Dahar (2011) menyatakan bahwa Bruner menganggap bahwa belajar penemuan sesuai dengan pencarian pengetahuan secara aktif oleh manusia dan dengan sendirinya memberikan hasil yang paling baik. Berusaha sendiri untuk mencari pemecahan masalah serta pengetahuan yang menyertainya, menghasilkan pengetahuan yang benar-benar bermakna. Pengetahuan yang diperoleh dengan belajar penemuan menunjukkan beberapa kebaikan. Pertama, pengetahuan itu bertahan lama atau lama diingat atau lebih mudah diingat bila dibandingkan dengan pengetahuan yang dipelajari dengan cara-cara lain. Kedua, hasil belajar penemuan mempunyai efek transfer yang lebih baik daripada hasil belajar lainnya. Ketiga, secara menyeluruh belajar penemuan meningkatkan penalaran siswa dan kemampuan untuk berpikir secara bebas.
Menurut Depdiknas (2008) modul adalah seperangkat bahan ajar yang disajikan secara sistematis sehingga penggunaannya dapat belajar dengan atau tanpa seorang fasilitator/ guru. Suryosubroto (1983) menyatakan bahwa dalam proses belajar mengajar, penggunaan modul dapat merangsang situasi belajar yang lebih mengaktifkan siswa untuk memecahkan masalah-masalah dibawah pengawasan dan bimbingan guru.

Tujuan penelitian ini adalah (1) mengembangkan modul pembelajaran kimia materi pokok larutan elektrolit dan nonelektrolit berbasis inkuiri terbimbing. (2) mengungkapkan validitas, praktikalitas, dan efektifitas modul pembelajaran kimia materi pokok larutan elektrolit dan nonelektrolit berbasis inkuiri terbimbing yang dihasilkan.

\section{METODE PENELITIAN}

Penelitian yang akan dilakukan ini termasuk dalam kategori penelitian dan pengembangan, yang menghasilkan suatu produk baru dalam pembelajaran yaitu modul pembelajaran kimia untuk mengajarkan materi pokok larutan elektrolit dan nonelektrolit pada siswa kelas X SMA. Model pengembangan yang digunakan dalam penelitian ini adalah model 4D. Menurut Thiagarajan, dkk dalam Trianto (2010: 93) model ini terdiri dari 4 tahap yaitu pendefinisian (define), perancangan (design), pengembangan (develop), dan penyebaran (desseminate).

Adapun langkah-langkahnya sebagai berikut: (1) Tahap pendefinisian (define). Tahap ini meliputi berapa langkah pokok, yaitu (a) analisis ujung depan, (b) analisis tugas, (c) analisis konsep, (d) analisis siswa (Trianto, 2010: 93). (2) Tahap perancangan. Tujuan tahap ini adalah merancang bahan ajar berupa modul jenis inkuiri terbimbing yang akan dikembangkan untuk mengajarkan materi materi pokok larutan elektrolit dan nonelektrolit di SMA. Tahap ini terdiri dari empat langkah yaitu, (a) penyusunan tes, (b) pemilihan bahan ajar, (c) pemilihan format, dan (d) rancangan awal produk yang akan dikembangkan. (3) Tahap pengembangan. Pada tahapan ini dilakukan modifikasi modul yang dihasilkan pada tahap perancangan, sebelum menjadi produk akhir yang siap untuk digunakan. Dalam tahap ini dilakukan tiga langkah yaitu validasi (penilaian) produk, revisi, dan uji coba. (4) Tahap penyebaran. 
Tahap ini merupakan tahap penggunaan modul yang telah dikembangkan pada skala yang lebih luas misalnya di kelas lain, di sekolah lain, oleh guru yang lain. Tahap penyebaran ini dilakukan untuk mempromosikan produk pengembangan agar bisa diterima pengguna, baik individu, suatu kelompok atau sistem. Namun karena keterbatasan penulis untuk melakukan promosi dan keterbatasan penulis untuk bekerjasama dengan penerbit untuk melakukan promosi yang lebih luas dan para praktisi pendidikan, maka penelitian ini hanya terbatas pada tahap pengembangan. Prosedur penelitian digambarkan dalam diagram alur seperti terlihat pada gambar 1 di bawah ini. Setelah modul dinyatakan valid oleh validator, maka dilakukan uji coba terbatas untuk mendapatkan data tentang praktikalitas dan efektivitas penggunaan modul di lapangan, serta untuk mengetahui pemahaman siswa mengenai konsep yang terdapat dalam modul.

Penelitian ini hanya dilaksanakan sampai tahap pengembangan (develop). Ujicoba ini dilakukan pada siswa yang belum mempelajari materi pokok larutan elektrolit dan nonelektrolit. Langkah-langkah yang dilakukan dalam pengembangan bahan ajar berupa modul berbasis inkuiri ini dapat dirinci sebagai berikut ini:

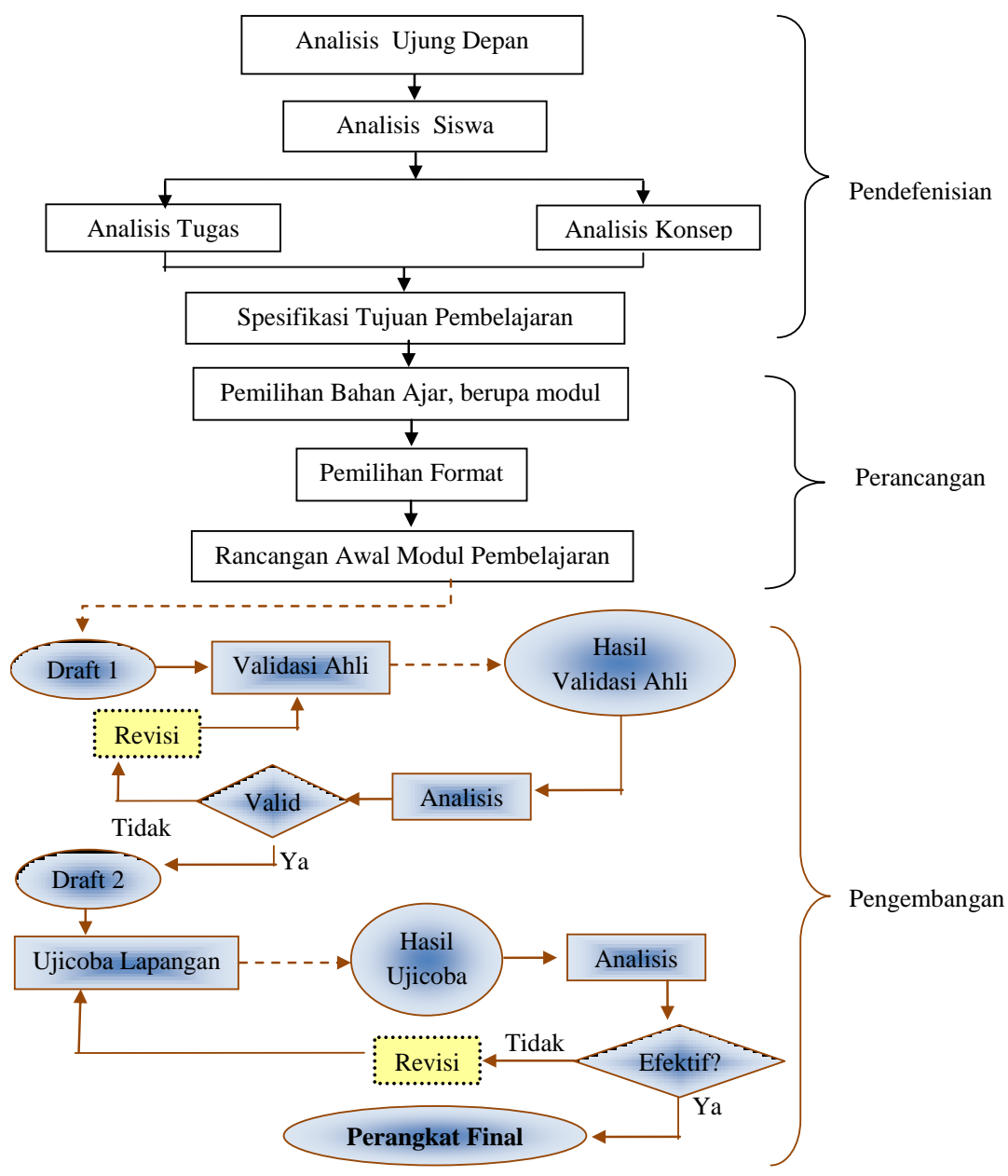

Gambar 1. Diagram Alir Pengembangan Modul Pembelajaran modifikasi dari Model 4-D (Muchayat, 2011: 202)

Setelah modul pembelajaran kimia berbasis inkuiri terbimbing dinyatakan valid oleh validator, maka dilakukan ujicoba terbatas untuk mendapatkan data tentang praktikalitas dan efektivitas penggunaan modul di lapangan, serta untuk mengetahui pemahaman siswa mengenai konsep yang terdapat dalam modul pembelajaran kimia ini. Ujicoba ini dilakukan oleh guru mata pelajaran kimia pada siswa yang telah mempelajari materi pokok larutan elektrolit dan nonelektrolit di kelas X SMA. Produk yang sudah dihasilkan diujicobakan pada siswa kelas X SMA Negeri 1 Lubuk Alung. 
Jenis data yang dikumpulkan dalam penelitian ini adalah (a) Validitas produk, data validitas berupa hasil validasi produk yang dikembangkan berupa modul pembelajaran oleh validator yang ahli dibidangnya. (b) Praktikalitas produk, data praktikalitas diperoleh dari hasil uji coba terbatas di lapangan menyangkut kepraktisan dan keterlaksanaan produk yang dikembangkan. (c) Efektivitas, data efektivitas diperoleh berdasarkan hasil uji coba produk di lapangan menyangkut hasil belajar siswa menggunakan produk yang dikembangkan.

Instrumen yang digunakan dalam penelitian ini adalah (a) Lembar validasi modul pembelajaran. Lembar validasi modul yaitu berupa angket yang digunakan untuk menilai validitas isi dan validasi konstruk dari modul yang dihasilkan. Data yang didapatkan digunakan untuk mengetahui tingkat validitas modul pembelajaran yang dikembangkan. (b) Angket. Angket yang diberikan merupakan angket respon siswa dan respon guru terhadap modul yang digunakan selama proses pembelajaran berlangsung. Data angket digunakan untuk mengetahui praktikalitas pemakaian modul selama proses pembelajaran berlangsung. (c) Tes hasil belajar. Hasil belajar siswa yang diperoleh dari hasil tes digunakan untuk menentukan persentase keberhasilan siswa setelah mengikuti pembelajaran menggunakan modul. Data tes hasil belajar selanjutnya digunakan untuk melihat efektivitas modul yang dikembangkan dari segi hasil belajar siswa.

\section{HASIL DAN PEMBAHASAN}

\subsection{Hasil Tahap Pendefenisian (Define)}

Tahap pendefinisian dilakukan untuk melihat gambaran bagaimana kondisi di lapangan yang berkaitan dengan proses pembelajaran kimia kelas X SMA Negeri 1 Lubuk Alung. Pada tahap ini ada 4 hal yang dilakukan yaitu analisis ujung depan, analisis siswa, analisis tugas, dan analisis konsep, dengan uraian sebagai berikut:

Analisis Ujung Depan. Pada tahap ini dilakukan analisis terhadap kurikulum, karena proses pembelajaran yang dilaksanakan berpedoman pada kurikulum yaitu kurikulum KTSP. Pelaksanaan pembelajaran yang terdapat dalam KTSP menyatakan bahwa dalam proses pembelajaran menuntut siswa yang harus aktif dalam membangun pengetahuannya dan guru lebih berperan sebagai fasilitator dan motivator. Standar kompetensi (SK) pada materi pokok larutan elektrolit dan nonelektrolit adalah memahami sifat-sifat larutan nonelektrolit dan elektrolit, serta reaksi oksidasi-reduksi. Kompetensi dasar (SK) adalah mengidentifikasi sifat larutan nonelektrolit dan elektrolit berdasarkan data hasil percobaan. Berdasarkan analisis kurikulum dirancang modul pembelajaran, agar tuntutan kurikulum dapat tercapai. Penggunaan modul pembelajaran kimia berbasis inkuiri terbimbing pada materi pokok larutan elektrolit dan nonelektrolit dibuat berdasarkan siklus belajar inkuiri terbimbing dan siswa dibagi berkelompok. Dalam belajar kelompok, siswa bekerja sama membangun pemahaman dan pengetahuan, sehingga siswa belajar lebih banyak, mengerti lebih banyak dan mengingat lebih banyak apabila mereka bekerja sama (Hanson, 2006: 4).

Analisis siswa sebelum dilakukan pembelajaran di kelas terlebih dahulu dilakukan analisis siswa. Subjek uji coba pada penelitian ini adalah siswa kelas $\mathrm{X}$ SMA Negeri 1 Lubuk Alung yang usianya berkisar antara 16-17 tahun. Menurut Piaget taraf berpikir anak usia tersebut pada tahapan perkembangan operasional. Hal ini dijadikan pertimbangan dalam menyusun konsep-konsep dari materi pembelajaran. Berdasarkan hasil pengamatan dalam proses pembelajaran, dapat diketahui secara garis besar karakteristik cara belajar siswa adalah sebagai berikut: siswa mudah lupa terhadap konsep yang dipelajarinya jika siswa tersebut tidak dilibatkan dalam proses membangun pemahaman konsep; siswa yang menyimak dan menanggapi penyajian guru hanya siswa yang memiliki kemampuan lebih. Pada modul ini konsep-konsep utama yang akan diajarkan disusun secara sistematis serta mengaitkan satu konsep dengan konsep lain, sehingga diharapkan dapat memudahkan siswa dalam proses pemahaman.

Analisis Tugas. Pada analisis tugas dilakukan analisis terhadap SK dan KD yang akan dikembangkan untuk membuat modul pembelajaran kimia. Dalam penelitian ini yang dianalisis adalah SK 3 dan KD 3.1 tentang materi pokok larutan elektrolit dan nonelektrolit yang dipelajari di kelas X SMA. Berdasarkan hasil identifikasi SK dan KD yang terdapat dalam silabus, dijabarkan beberapa indikator pembelajaran. Indikator pembelajaran yang telah diuraikan, peneliti 
merancang modul pembelajaran kimia berbasis inkuiri terbimbing yang dapat membantu guru dan siswa dalam proses pembelajaran larutan elektrolit dan nonelektrolit.

Analisis Konsep. Analisis konsep dilakukan untuk mengidentifikasi konsepkonsep utama yang akan diajarkan. Khusus untuk materi pokok larutan elektrolit dan nonelektrolit tercakup dalam KD 3.1 yang dijabarkan menjadi lima indikator pembelajaran. Langkah selanjutnya yang dilakukan adalah menganalisis konsep-konsep yang akan diajarkan dalam materi pokok larutan elektrolit dan nonelektrolit. Konsepkonsep tersebut disusun secara sistematis sehingga membentuk suatu hubungan yang ditentukan dari indikator pembelajaran. Berdasarkan analisis konsep, dirancang modul pembelajaran kimia berbasis inkuiri terbimbing materi pokok larutan elektrolit dan nonelektrolit, agar indikator pembelajaran dapat tercapai.

\subsection{Hasil Tahap Perancangan (Designed)}

Setelah indikator pembelajaran dirumuskan, serta konsep-konsep ditetapkan, maka langkah selanjutnya adalah merancang modul pembelajaran kimia berbasis inkuiri terbimbing, yaitu sebagai berikut: (a) Merancang modul yang dilakukan dengan pemilihan format yang sesuai dengan format penulisan modul dalam buku Panduan Pengembangan Bahan Ajar dari Depdiknas tahun 2008. (b) Menetapkan judul materi pokok yang akan dikembangkan modul pembelajaran kimia berbasis inkuiri terbimbing. (c) Menentukan SK dan KD yang akan dikembangkan modul pembelajaran kimia berbasis inkuiri terbimbing. (d) Berdasarkan hasil identifikasi SK dan KD, maka langkah selanjutnya diuraikan indikator pembelajaran yang ingin dicapai. (e) Merancang model yang sesuai dengan indikator pembelajaran yang ingin dicapai. (f) Berdasarkan model yang disajikan pada modul, dibuatlah pertanyaan-pertanyaan kunci sehingga siswa dapat menemukan konsep dengan mengamati dan menyelidiki model yang diberikan. (g) Selanjutnya diberikan latihan yang merupakan aplikasi langsung dari konsep, sehingga dapat membantu siswa dalam memantapkan konsep.

\subsection{Hasil Tahap Pengembangan (Develop)}

Tahap pengembangan bertujuan untuk menghasilkan modul pembelajaran kimia berbasis inkuiri terbimbing yang layak digunakan dalam penelitian ini dan untuk pembelajaran kimia pada materi pokok larutan elektrolit dan noneletrolit. Pada tahap ini terdiri dari tiga langkah yaitu memvalidasi modul, menentukan praktikalitas, dan efektifitas dari modul pembelajaran kimia berbasis inkuiri terbimbing yang sudah dirancang untuk dilakukan dalam proses pembelajaran di kelas.

Kevalidan modul pembelajaran berbasis inkuiri terbimbing yang dihasilkan dapat diketahui dengan validasi oleh validator. Dalam penelitian ini, yang ditunjuk sebagai validator untuk menilai modul pembelajaran adalah dua orang dosen dan satu orang guru kimia. Hasil validasi selanjutnya dianalisis untuk mengetahui validitas modul baik dari segi kelayakan isi, kelayakan konstruk, komponen kebahasaan dan komponen kegrafisan.

Berdasarkan data validasi kelayakan isi modul pembelajaran kimia materi pokok larutan elektrolit dan nonelektrolit berbasis inkuiri terbimbing dari validator I dan III memiliki kategori kevalidan yang sangat tinggi dan validator II memiliki kategori kevalidan yang tinggi. Dari keempat komponen penilaian modul pembelajaran kimia diperoleh kesimpulan kategori kevalidan dari validator I dan III sangat tinggi sedangkan dari validator II memiliki kategori kevalidan yang tinggi. Walaupun kevalidan modul pembelajaran kimia telah tinggi, namun masih ada beberapa komponen yang harus diperbaiki.

Kepraktisan modul pembelajaran kimia berbasis inkuiri terbimbing dilihat dari keterpakaian produk dari hasil uji coba terbatas di lapangan menyangkut kepraktisan dan keterlaksanaan produk yang dikembangkan. Data praktikalitas diperoleh dari pemberian angket kepada guru mata pelajaran kimia dan angket respon siswa kelas X SMA Negeri 1 Lubuk Alung. penilaian kepraktisan modul pembelajaran kimia berbasis inkuiri terbimbing diperoleh sangat tinggi dengan nilai momen kappa sebesar 0,91. Dari hasil kepraktisan tersebut, maka modul pembelajaran ini dapat diterapkan pada proses pembelajaran di sekolah. Kepraktisan modul pembelajaran juga dilihat dari pemberian angket respon siswa terhadap produk ini, 
perolehan rata-rata momen kappa dari keseluruhan aspek yang dinilai yang mencapai 0,95 dengan kategori kepraktisan sangat tinggi.

Efektifitas, uji efektifitas dari modul pembelajaran kimia berbasis inkuiri terbimbing dilihat dari perubahan hasil belajar siswa sebelum (pre tes) dan sesudah (post tes) menggunakan produk yang dikembangkan. Soal yang diberikan kepada siswa berbeda pada saat dilakukan pre tes dan post tes, tetapi kisi-kisi soal dan tingkat kesulitan dari soal tersebut sama. Uji coba dilakukan pada 30 orang siswa, terlihat adanya perbedaan hasil belajar siswa pada saat dilakukan ujian tes awal dan tes akhir. Uji efektifitas yang dilakukan pada hasil belajar siswa terdapat perbedaan yang cukup signifikan. Dimana dari ujian hasil belajar siswa sebelum menggunakan produk (pre tes) diperoleh ratarata ujian siswa 63,8 sedangkan ujian sesudah (post tes) menggunakan produk yang dikembangkan diperoleh rata-rata ujian siswa menjadi 85,8 dengan kategori baik, yang artinya efektifitas dari modul sudah tinggi. Hal ini dapat disimpulkan bahwa pemahaman siswa menggunakan modul pembelajaran kimia berada pada kategori baik, sehingga produk sangat efektif untuk digunakan dalam pembelajaran.

\section{KESIMPULAN}

Berdasarkan hasil pengembangan, maka penelitian pengembangan ini dapat disimpulkan sebagai berikut: (a) Modul pembelajaran kimia pada materi pokok larutan elektrolit dan nonelektrolit berbasis inkuiri terbimbing telah dapat digunakan dalam proses pembelajaran kimia di sekolah. (b) Validitas produk modul pembelajaran kimia pada materi pokok larutan elektrolit dan nonelektrolit berbasis inkuiri terbimbing yang dikembangkan telah sesuai dengan kurikulum dan konsep yang benar serta sudah menggunakan bahasa dan komunikasi modul pembelajaran yang baik. (c) Praktikalitas modul pembelajaran kimia pada materi pokok larutan elektrolit dan nonelektrolit berbasis inkuiri terbimbing menunjukkan tingkat sangat tinggi. hal ini mengungkapkan bahwa modul pembelajaran yang dikembangkan memiliki kategori kepraktisan sangat praktis digunakan dalam proses pembelajaran. (d) Efektifitas modul pembelajaran kimia pada materi pokok larutan elektrolit dan nonelektrolit berbasis inkuiri terbimbing menunjukkan bahwa modul pembelajaran yang dikembangkan sudah baik, yang

\section{DAFTAR PUSTAKA}

Dahar, Ratna.W. 2011. Teori-teori Belajar dan Pembelajaran. Bandung: Erlangga.

Departemen Pendidikan Nasional. 2008. Pengembangan Bahan Ajar. Jakarta: Departemen Pendidikan Nasional, Direktorat Jenderal Manajemen Pendidikan Dasar dan Menengah, Direktorat Pembinaan Sekolah Menengah Atas.

Hanson, David. M. 2005. Designing ProcessOriented Guided-Inquiry Activities. In Faculty Guidedbook: A Comprehensive Tool For Improving Faculty Performance, ed. S. W. Beyerlein and D. K. Apple. Lisle, IL: Pacific Crest.

Hanson, David. M. 2006. Instructor's Guided to Process-Oriented Guided-Inquiry Learning. Lisle, IL: Pacific Crest.

Muchayat. 2011. Pengembangan Perangkat Pembelajaran Matematika dengan Strategi Ideal Problem Solving Bermuatan Pendidikan Karakter. JPP 2011 (2): 208

Sanjaya, Wina. 2008. Strategi Pembelajaran Berorientasi Standar Proses Pendidikan. Jakarta: Kencana Prenada Media Group.

Suryosubroto, B. 1983. Sistem Pengajaran Dengan Modul. Yogyakarta: PT. Bina Aksara.

Trianto. 2010. Model Pembelajaran Terpadu. Jakarta: Bumi Aksara. 
ISSN 1412-5455 Jurnal Sains dan Teknologi Vol. 16 No.1, Juni 2016:1-113 